\title{
FIREFIGHTING COMBAT WITH FIRE RETARDANTS AT DIFFERENT CONCENTRATIONS
}

\author{
Nilton Cesar Fiedler ${ }^{1 *}$, Guilherme Rizo Larcerda ${ }^{1}$, Antonio Henrique Cordeiro Ramalho ${ }^{1}$, Leandro Christo \\ Berude $^{1}$, Felipe Patricio das Neves ${ }^{1}$, Carla Krulikowski Rodrigues ${ }^{2}$
}

${ }^{1}$ Federal University of Espírito Santo, Departament of Forest and Wood Science, Jerônimo Monteiro, Espírito Santo, Brazil niltoncesarfiedler@yahoo.com.br*; henriquecr2012@hotmail.com; patriciofire193190@gmail.com; leandroberude@gmail.com

${ }^{2}$ State University of Centro-Oeste, Irati, Paraná, Brazil - carlakr@gmail.com

Received for publication: 18/09/2018 - Accepted for publication: 26/07/2019

\begin{abstract}
Resumo
Combate a incêndios florestais com uso de retardantes de fogo em diferentes concentrações. Os incêndios florestais são responsáveis pela destruição de milhões de hectares de florestas no mundo e geram diversos prejuízos econômicos, sociais e paisagísticos. Assim, o desenvolvimento de técnicas de combate torna-se cada vez mais necessário. Neste contexto, objetivou-se avaliar a eficiência de diferentes retardantes de fogo e suas concentrações no combate aos incêndios florestais, levando em consideração os tempos e intensidades de queima do material combustível. O estudo foi conduzido no interior de um plantio de Eucalyptus spp., sendo conduzido o experimento em três retardantes de fogo (Silv-Ex; F-500; e HoldFire) e em três concentrações $(1 \% ; 1,5 \%$; e $2 \%)$, além da testemunha composta apenas por água no combate. Para isso, foi utilizado um delineamento inteiramente casualizado e a análise estatística foi feita a partir de arranjos experimentais (fatorial $3 \times 3$ ). As variáveis avaliadas durante o processo de queima foram: os tempos de queima (tempos gastos para que as chamas consumissem todo o material combustível das extremidades com e sem o produto) e a intensidade de queima. Os resultados a respeito do tempo e intensidade de queima em relação às dosagens mostraram uma tendência de decréscimo à medida que se aumentavam as doses, classificando a maior dose (2\%) como a mais eficiente. Já no caso dos retardantes, todos foram eficientes, destacando-se o Silv-Ex como o mais indicado visto que diminuiu significativamente a intensidade de queima e elevou o tempo de queima do material combustível.
\end{abstract}

Palavras-chave: intensidade de queima, proteção florestal, material combustível.

\begin{abstract}
Forest fires are responsible for the destruction of millions of hectares of forest worldwide, and they lead to diverse economic, social, and landscape damage. Thus, the development of techniques to combat them has become increasingly necessary. In this context, this study aims to evaluate the efficiency of different fire retardants at different concentrations in fighting forest fires, considering the burning times and intensities of forest fuel. The study was conducted inside Eucalyptus spp. stands using three fire retardants (Silv-Ex, F-500, and HoldFire) at three concentrations (1\%, $1.5 \%$, and $2 \%)$, in addition to a water-only control. A completely randomized design was used, and the statistical analysis was completed based on experimental arrangements (factorial $3 \times 3$ ). Variables evaluated during the burning process were as follows: burning times (the time required for the flames to consume all forest fuel within the sample, with and without the retardant) and intensity of burning. Results regarding the time and intensity of burning in relation to the concentrations indicated a decreasing trend as the latter were increased, classifying the highest dose $(2 \%)$ as the most efficient. For the retardants, all were observed to be efficient, with Silv-Ex being the most appropriate as it significantly reduced the burning intensity and increased the burning time of the forest fuel.

Keywords: burning intensity, forest protection, fuel materials.
\end{abstract}

\section{INTRODUCTION}

Forest fire can be understood as any uncontrolled fire that occurs in vegetation and is either anthropic or natural in origin. In general, forest fires are responsible for the destruction of millions of hectares of forests worldwide and generate widespread economic, social, landscape, and soil damage, which may occur in reforestation areas, conservation units, preservation areas, farms, roadsides, and surrounding urban areas (WESTERLING; BRYANT, 2008; SOUTO et al., 2009; TORRES et al., 2011; BOSCARDIN et al., 2014; McKENZIE et al., 2014; KNELMAN et al., 2017; RODRÍGUEZ et al., 2017).

In Brazil, fires are classified as the biggest catastrophe that a forest stand can suffer, as they cause economic damage, contribute to climate change, and endanger human and animal lives. (DINIS; CARVALHO, 2011; SOUZA et al., 2012). The National Institute for Space Research (INPE) recorded an annual average of 38,609 outbreaks of fires in the Brazilian territory from 2012 to 2018, and statistical evidence shows that the number of fires tend to increase as a result of unusual or cyclical global climate changes related to El Niño and La

FLORESTA, Curitiba, PR, v. 50, n. 1, p. 1107 - 1112, jan/mar 2020.

Fiedler, N. C. et.al.

ISSN eletrônico 1982-4688

1107

DOI: 10.5380/rf.v50 i1.61609 
Niña and from the indiscriminate and irrational use of fire by humans (BATISTA, 2009; TETTO et al., 2015; TORRES et al., 2016; INPE, 2017).

Although there are numerous preventive and firefighting techniques, these do not solve or prevent all occurrences (FIEDLER et al., 2015). Thus, the improvement of such techniques is always of high importance to eradicate or at least minimize the damage caused by the conflagrations.

The evolution of forest firefighting methods highlights an increase in the use of chemical products incorporated in water to enhance their efficiency, called flame or fire retardants (BATISTA, 2009). The potentiating characteristics of fire retardants are extremely important because of the difficulty of obtaining water in the regions of fire occurrence, and the favored ones provide this function at a relatively low cost (CANZIAN et al., 2018).

Brazil is not yet endowed with legislation that regulates the use and quality of these products, or even advises users in the correct methods and quantities to be used (PIERONI et al., 2017). One of the biggest limitations on the use of fire retardants in Brazil is high prices, as the vast majority of them are imported.

From the above information, it is evidently necessary to study different retardants and the possibility of maintaining the quality of their performance at lower concentrations, to maximize the effects of water with such products and to reduce costs. Thus, the objective was to evaluate the effectiveness of combatting forest fires using the fire retardants in different concentrations. The hypotheses that guide the present study are as follows: a) the natural base retardant used in the present research will present statistically inferior results to the chemical ones; and $b$ ) higher product concentrations will ensure more promising results.

\section{MATERIAL AND METHODS}

\section{Study area}

The study was conducted in an experimental area of the Federal University of Espirito Santo, located in the municipality of Jerônimo Monteiro, southern Espírito Santo State, Brazil, between the coordinates $20^{\circ} 47^{\prime} 45^{\prime \prime} \mathrm{S}$ and $41^{\circ} 24^{\prime} 21^{\prime \prime} \mathrm{W}$. The climate is classified, according to Köppen, by the Aw type, whose average annual temperature is $23^{\circ} \mathrm{C}$ and average rainfall of $1200 \mathrm{~mm}^{-1} \mathrm{r}^{-1}$ (INCAPER, 2013).

\section{Fuel material used}

In all plots, $2.5 \mathrm{~kg} \mathrm{~m}^{-2}$ of dry Eucalyptus spp. included in floor-mounted windrows (Figure 1) was used as standardized fuel material to be treated with the retardants.

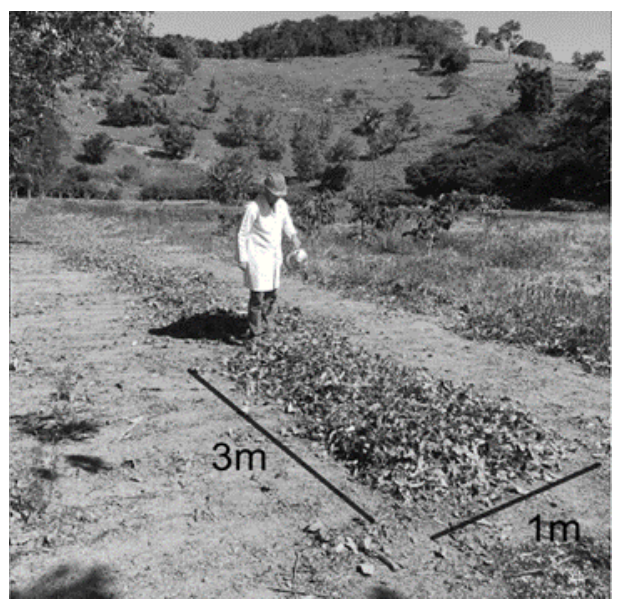

Figure 1. Preparation of plots with litter.

Figura 1. Confecção das parcelas com serapilheira.

The moisture and dry matter quantification of the fuel material was determined by oven drying $\left(65^{\circ} \mathrm{C}\right)$ it until it reached a constant weight. Subsequently, a sample of $3 \mathrm{~kg}$ of forest fuel was allocated to a template of 1 $\mathrm{m}^{2}$.

The moisture content of the fuel material was determined by a three-repetition sample of $1 \mathrm{~m}^{2}$ of the fuel material, which corresponded on average to $2.95 \mathrm{~kg} \mathrm{~m}^{-2}$ wet litter.

\section{Methods used}

Each plot was subjected to a controlled application of $0.5 \mathrm{~L}$ of solution or water (control) per square meter $\left(\mathrm{m}^{2}\right)$, as proposed by Fiedler et al. (2015), with retardant treatments differentiated by type and concentration $(1 \%$, $1.5 \%$, and $2 \%$ ). The concentration recommended by the manufacturers is $1 \%$; however, it was decided that higher 
concentrations would be applied to determine whether the efficiency of the products would increase proportionally with the consequent reduction in the amount of water. This is especially important considering the difficulty in obtaining water at the time of firefighting. The retardants used in this study were as follows:

- Silv-Ex (SV): A liquid used for Class A fires, with recommended concentrations ranging from $0.1 \%$ to $1 \%$ in fresh, brackish, or saltwater;

- F-500 (F5): A liquid with recommended concentrations that can range from $0.5 \%$ to $3 \%$ according to fire class (Classes A, B, and D); and

- HoldFire (HF): A biodegradable additive that enhances water use in Class A fires.

With the aid of an adjustable sprayer, the solution containing the fire retardant was mixed with water to achieve the desired concentration in the intended spaces $(1 \mathrm{~m} \mathrm{x} 1 \mathrm{~m})$, and then was homogeneously applied before combustion began.

\section{Sampling procedure}

The experimental area consisted of 30 plots, with dimensions of $1 \mathrm{~m}$ x $3 \mathrm{~m}$. Within a plot, the retardant application area was $1 \mathrm{mx} 1 \mathrm{~m}$, and the ignition area of the fire that defined the direction of fire was the remaining $2 \mathrm{~m} \times 1 \mathrm{~m}$ (Figure 2). In total, there were nine treatments with three repetitions each. The other plots were the control plots treated with water only.

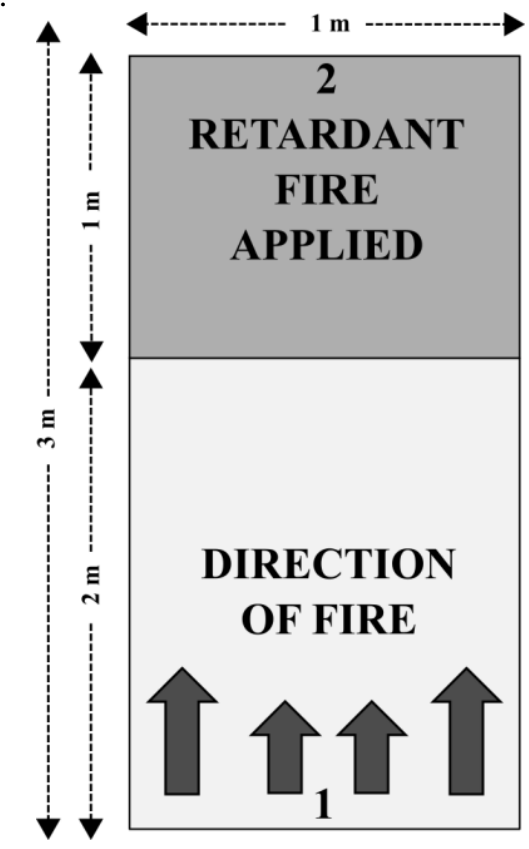

Figure 2. Retardants and fire application scheme.

Figura 2. Esquema de aplicação dos retardantes de fogo.

After the application of the retardants, each fire was ignited in the forest fuel so that the flames followed the direction of propagation until they reached the end that was subjected to the treatments. The first part of the windrows only served to form the line of fire, while the distance, used for calculation purposes, was accounted for only in the second part.

\section{Fire characterization}

Relative humidity, wind speed, and plot burning time with and without the product were evaluated. The characterization of fire behavior was performed using the burning intensity equation (1), proposed by Byram (1959)

$$
\mathrm{I}=\mathrm{H} . \mathrm{w} . \mathrm{r}
$$

Where, $\mathrm{I}=$ burning intensity $\left(\mathrm{kcal} . \mathrm{m}^{-1} \mathrm{~s}^{-1}\right) ; \mathrm{H}=$ calorific value of dominant fuel material (4.947 kcal); $\mathrm{w}=$ load of available forest fuel $\left(\mathrm{kg} \mathrm{m}^{-2}\right)$; and $\mathrm{r}=$ fire propagation velocity $\left(\mathrm{m} \mathrm{s}^{-1}\right)$.

\section{Statistical analysis}

For statistical analysis of time and intensity values, the experimental arrangement was factorial, considering the types of retardants and their concentrations, the control with water (treatments), and three plots as

FLORESTA, Curitiba, PR, v. 50, n. 1, p. 1107 - 1112, jan/mar 2020. 
repetitions. Initially, the analysis of variance (ANOVA) was applied, and subsequently, for the comparison of means, the Tukey test was applied at 5\% probability of error with the aid of the SISVAR 5.6 program.

Using Excel 2013 software, it was verified, based on linear regression, that a functional relationship existed between the independent variables (product concentrations) and the dependent variables (burning times and intensities).

\section{RESULTS}

The mean values and their respective standard deviations of mass, humidity, height, and density of the forest fuel are presented in Table 1.

Table 1. Average values of the mass of the forest fuel, humidity, height, and apparent density.

Tabela 1. Valores médios da massa do material combustível, umidade, altura e densidade aparente.

\begin{tabular}{cccccc}
\hline $\begin{array}{c}\text { Wet Fuel Material } \\
\left(\mathbf{k g ~ m}^{-2}\right)\end{array}$ & $\begin{array}{c}\text { Dry Fuel Material } \\
\left(\mathbf{k g ~ m}^{-\mathbf{2}}\right)\end{array}$ & $\begin{array}{c}\text { Dry Fuel Material } \\
\left(\mathbf{M g ~ h a}^{-\mathbf{1}}\right)\end{array}$ & $\begin{array}{c}\text { Moisture } \\
(\mathbf{\%})\end{array}$ & $\begin{array}{c}\text { Height Fuel } \\
\text { Material } \\
(\mathbf{c m})\end{array}$ & $\begin{array}{c}\text { Apparently } \\
\mathbf{d e n s i t y} \\
\left(\mathbf{k g ~ m}^{-\mathbf{3}}\right)\end{array}$ \\
\hline $2.5 \pm 0.09$ & $2.09 \pm 0.15$ & $20.9 \pm 1.48$ & $19.61 \pm 4.55$ & 15 & $16.66 \pm 0.58$ \\
\hline
\end{tabular}

Table 2 presents the results of the analysis of variance (ANOVA) for the burning times and intensities.

Table 2. Results of the ANOVA of the burning times and intensities of three fire retardants applied at three different concentrations.

Tabela 2. Resultados da ANOVA dos tempos e intensidades de queima em três retardantes de fogo submetidos à três diferentes concentrações.

\begin{tabular}{|c|c|c|c|}
\hline \multirow{2}{*}{ Variation source } & \multirow{2}{*}{ Sum of squares } & Medium square & Fc (significance) \\
\hline & & \multicolumn{2}{|c|}{ Time (seconds) } \\
\hline Retardant (A) & 38817.85 & 19408.93 & $41.30^{*}$ \\
\hline Dose (B) & 22814.52 & 11407.26 & $24.27^{*}$ \\
\hline Retardant $\mathrm{x}$ concentration & 5854.37 & 1463.59 & $3.11^{*}$ \\
\hline Average & - & 521.81 & - \\
\hline- & - & \multicolumn{2}{|c|}{ Intensity $\left(\mathrm{kcal} \mathrm{s}^{-1} \mathrm{~m}^{-1}\right)$} \\
\hline Retardant (A) & 313.4 & 156.7 & $33.42^{*}$ \\
\hline Dose (B) & 183.48 & 91.74 & $19.50^{*}$ \\
\hline Retardant $\mathrm{x}$ concentration & 40.37 & 10.09 & $2.15^{\mathrm{ns}}$ \\
\hline Average & - & 47.89 & - \\
\hline $\mathrm{R}^{2}$ & - & 0.987 & - \\
\hline
\end{tabular}

The ANOVA results for burning times demonstrated the existence of significant interaction between the main factors (retardants and doses) by Tukey test at $5 \%$ probability of error, which led to the need to proceed with the unfolding of such factors (Table 3 ).

Table 3. Interaction between the $\mathrm{AxB}$ and $\mathrm{BxA}$ treatments and the control.

Tabela 3. Interação entre os tratamentos $\mathrm{AxB}$ e BxA e a testemunha.

\begin{tabular}{|c|c|c|c|c|c|c|c|c|}
\hline \multicolumn{9}{|c|}{ Time (seconds) } \\
\hline \multicolumn{9}{|c|}{ Concentration on Retardants } \\
\hline \multirow{4}{*}{$1 \%$} & SV & $508.7 \mathrm{a}$ & \multirow{4}{*}{$1,5 \%$} & $\mathbf{S V}$ & $585.3 \mathrm{a}$ & \multirow{4}{*}{$2 \%$} & SV & $614.3 \mathrm{a}$ \\
\hline & HF & $504.3 \mathrm{a}$ & & HF & $501.0 \mathrm{~b}$ & & HF & $552.7 \mathrm{~b}$ \\
\hline & F5 & $454.0 \mathrm{~b}$ & & F5 & $464.0 \mathrm{~b}$ & & F5 & $512.0 \mathrm{~b}$ \\
\hline & Witness treatment & $273.0 \mathrm{c}$ & & Witness treatment & $261.0 \mathrm{c}$ & & Witness treatment & $255.0 \mathrm{c}$ \\
\hline \multicolumn{9}{|c|}{ Retardants on Concentration } \\
\hline \multirow{4}{*}{ SV } & $1 \%$ & $501.0 \mathrm{~b}$ & \multirow{4}{*}{ HF } & $1 \%$ & $508.7 \mathrm{~b}$ & \multirow{4}{*}{ F5 } & $1 \%$ & $454.0 \mathrm{~b}$ \\
\hline & $1,5 \%$ & $504.3 \mathrm{~b}$ & & $1,5 \%$ & $585.3 \mathrm{a}$ & & $1,5 \%$ & $464.0 \mathrm{~b}$ \\
\hline & $2 \%$ & $552.7 \mathrm{a}$ & & $2 \%$ & $614.3 \mathrm{a}$ & & $2 \%$ & $512.0 \mathrm{a}$ \\
\hline & Witness treatment & $273.0 \mathrm{c}$ & & Witness treatment & $261.0 \mathrm{c}$ & & Witness treatment & $255.0 \mathrm{c}$ \\
\hline
\end{tabular}

Where: *Means followed by the same letter in the column do not differ from each other by the Tukey test at $5 \%$ probability.

The analysis of variance for the burning intensity showed no significant interaction between the main factors (retardants and doses) by Tukey test at 5\% probability of error (Table 4).

Table 4. Intensity of burning of three concentrations of fire retardants and of the control without retardant.

Tabela 4. Intensidade de queima de três doses de retardantes químicos de fogo e da testemunha sem retardante. 


\begin{tabular}{cc|cc}
\hline \multicolumn{4}{c}{ Burning intensity $\left(\mathrm{kcal} \mathrm{m}^{\mathbf{- 1}} \mathbf{~ s}^{\mathbf{- 1}}\right)$} \\
\hline Concentrations & Witness treatment & Retardants \\
\hline Witness treatment & $94.12 \mathrm{a}$ & $\mathbf{F 5}$ & $52.12 \mathrm{~b}$ \\
$\mathbf{1 \%}$ & $50.83 \mathrm{~b}$ & $\mathbf{H F}$ & $47.75 \mathrm{c}$ \\
$\mathbf{1 , 5 \%}$ & $48.34 \mathrm{~b}$ & $\mathbf{S V}$ & $43.78 \mathrm{~d}$ \\
\hline $\mathbf{2 \%}$ & $44.49 \mathrm{c}$ &
\end{tabular}

From the graphical representation in Figure 3, it is seen that as the retardant concentration increases, the burning intensities decrease, and the burning times increase.

A

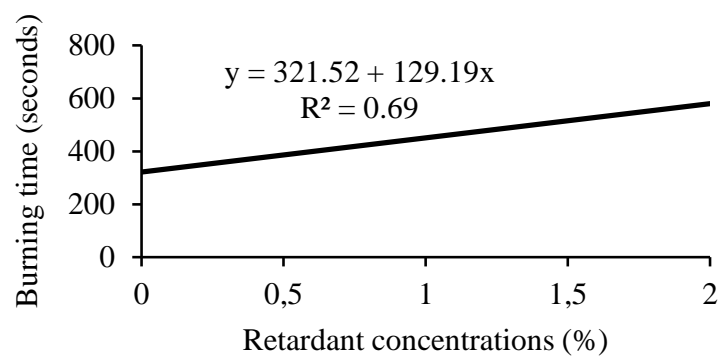

B

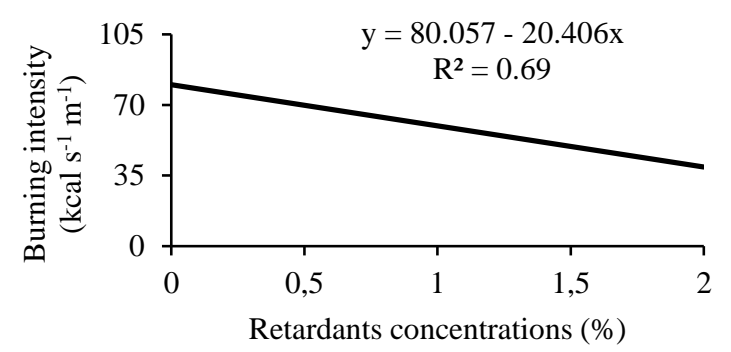

Figure 3. (A) Burning time (s); and (B) Intensity of burning $\left(\mathrm{kcal} \mathrm{m}^{-1} \mathrm{~s}^{-1}\right)$ of three different treatments with retardants in their respective concentrations and the control.

Figura 3. (A) Tempo de queima (segundos); e (B) Intensidade de queima ( $\mathrm{kcal} \mathrm{m}^{-1} \mathrm{~s}^{-1}$ ) em três diferentes tratamentos com retardantes em suas respectivas doses e a testemunha.

\section{DISCUSSION}

The amount of dry forest fuel used in the present study was $20.9 \mathrm{Mg} \mathrm{ha}^{-1}$. This value meets the reality of Brazilian planted forests, because according to Souza et al. (2003), the amount of surface forest fuel in a 7-yearold Eucalyptus dunii Maiden forest approached $22 \mathrm{Mg} \mathrm{ha}^{-1}$. Already, the density of the material, when compared to the results found by White et al. (2014) in eucalyptus forests on the northern coast of Bahia State, Brazil, was considered low, as they found it to be $19.95 \mathrm{~kg} \cdot \mathrm{m}^{-3}$, approximately $17 \%$ more than that found in this research $\left(16.66 \mathrm{~kg} \cdot \mathrm{m}^{-3}\right)$.

The results on the intensity of burning were very interesting, since the expected fire retardants and higher concentrations led to a decrease of these values. Regarding the concentrations, the concentration of $2 \%$ emerged prominent, as it reduced the burning intensity by approximately 53\% in comparison to the control with only water. These results corroborate those found by Canzian et al. (2016), who obseved an inversely proportional relationship between retardant doses and burning intensity.

The retardant that obtained the best results on burning intensity was the SV, showing a reduction close to $54 \%$ compared to the control with water alone. It is also noteworthy that HF is an organic-based retardant that is little-known in the market, and it was able to reduce the intensity of burning by $51 \%$ compared to the control. Similar results were found by Maraboti et al. (2016) when studying the intensity of burning in forest fuels subjected to different fire retardants. The authors found, SV to be the best treatment, coincidentally, the F5 to be the worst.

Regarding the burning times, the trend remained as expected, with the highest doses producing the best results. However, it is noteworthy that $\mathrm{SV}$ was more effective at all doses, and only at $1 \%$ dosing did it match the HF results. The SV showed its best results in the highest dosage (2\%), presenting about $102 \%$ increase in the burning time compared to the control without retardant. The HF presented similar results in the doses of $2 \%$ and $1.5 \%$, presenting increase in the burning time in relation to the control, in the class of $125 \%$ and $124 \%$, respectively. The F5 was more efficient in the dosage of $2 \%$, which improved the burning time by $101 \%$ compared to its control.

\section{CONCLUSIONS}

- Among the three retardants studied and the water-only control, the treatment that presented the best results, at all concentrations, both for time and intensity of burning, was Silv-Ex; therefore, it was considered the most efficient under the conditions analyzed;

- Concentrations tended to decrease burning intensity and increase burning time of the forest fuel as they were increased, rendering the highest dose (2\%) the most efficient; and 
- As organic-based retardant is a newly developed product, it was quite effective in combating forest fires given the results presented.

\section{ACKNOWLEDGMENT}

This study was financed in part by the Coordenação de Aperfeiçoamento de Pessoal de Nível Superior Brasil (CAPES) - Finance Code 001.

\section{REFERENCES}

BATISTA, A. C. O uso dos retardantes no combate aéreo aos incêndios florestais. Floresta, Curitiba, v. 39, p. 5-10, 2009.

BOSCARDIN, J.; COSTA, E. C.; DELABIE, J. H. C.; GARLET, J. Efeito do fogo sobre a riqueza de formigas (Hymenoptera: Formicidae) associadas à Pinus elliottii Engelm. no Sul do Brasil. Ciência Florestal, Santa Maria, v. 24, n. 4, p. 1031-1040, 2014.

BYRAM, G. M. Combustion of forest fuels. In: DAVIS, K.P. Forest fire - control and use. New York: McGraw Hill, 1959. p. 77-84.

CANZIAN, W. P.; FIEDLER, N. C.; BRINATE, I. B.; JUVANHOL, R. S.; BIGHI, K. N. Diferentes concentraç̃os de retardante de fogo em plantios de eucalipto. Nativa, Sinop, v. 4, n. 4, p. 195-198, 2016.

CANZIAN, W. P. FIEDLER, N. C.; LOUREIRO, E. B.; BERUDE, L. C. Eficiência do uso da água em métodos de combate a incêndios em florestas plantadas. Nativa, Sinop, v. 6, n. 3, p. 309-312, 2018.

DINIS, G.; CARVALHO, A. As alterações climáticas e os incêndios florestais: Potenciais impactes na procura turística do Parque Natural das Serras de Aire e Candeeiros. Turismo e Desenvolvimento, Aveiro, v. 2, n. 16, p. 85-95, 2011.

FIEDLER, N. C.; CANZIAN, W. P.; MAFIA, R. G.; RIBEIRO, G. A.; KRAUSE JUNIOR, J. Intensidade de queima de diferentes retardantes de fogo. Árvore, Viçosa, v. 39, n. 4, p. 691-696, 2015.

INSTITUTO CAPIXABA DE PESQUISA, ASSISTÊNCIA TÉCNICA E EXTENSÃO RURAL - INCAPER. Programa de assistência técnica e extensão rural PROATER 2011 - 2013. Vitória - ES, 2013.

INSTITUTO NACIONAL DE PESQUISAS ESPACIAIS - INPE. INFOQUEIMA - Boletim mensal de monitoramento. v. 2, n. 12, 2017.

KNELMAN, J. E. et al. Rapid Shifts in Soil Nutrients and Decomposition Enzyme Activity in Early Succession Following Forest Fire. Forests, Basel, v. 8, n. 347, p. 1-12, 2017.

MARABOTI, V. M.; GONÇALVES, S. B.; CANZIAN, W. P.; FIEDLER, N. C.; MENDONÇA, A. R. Fire Retardantes Different Efficiency In Eucalyptus Plantations In The South Of Espírito Santo, Brazil. Australian Journal of Basic and Applied Sciences, Perth, v. 10, n. 9, p. 24-29, 2016.

McKENZIE, D. et al. Smoke consequences of new wildfire regimes driven by climate change. Earth's Future, Hoboken, v. 2, p. 35-59, 2014.

PIERONI, M. C.; LEONEL, J.; FILLMANN, G. Retardantes de chama bromados: Uma revisão. Química Nova, São Paulo, v. 40, n. 3, p. 317-326, 2017.

RODRÍGUEZ, M. P. R.; RODRÍGUEZ, Y. C.; SIERRA, C. A. M.; BATISTA, A. C.; TETTO, A. F. Relación entre variables meteorológicas e incêndios forestales em la provincia Pinar Del Río, Cuba. Floresta, Curitiba, v. 47, n. 3, p. 343-352, 2017.

SOUTO, P. C. et al. Quantificação do material combustível em plantios florestais e em remanescente de Mata Atlântica no brejo da Paraíba, Brasil. Engenharia Ambiental, Espírito Santo do Pinhal, v. 6, n. 2, p. 473-481, 2009.

SOUZA, H. N.; ARAÚJO, T. G.; RIBEIRO, G. A. Avaliação da eficiência de um gel hidroretentor como retardante de fogo. Árvore, Viçosa, v. 36, n. 3, p. 471-477, 2012.

TETTO, A. F.; SOARES, R. V.; BATISTA, A. C.; WENDLING, W. T. Incêndios florestais atendidos pela Klabin do Paraná no período de 1965 a 2009. Cerne, Curitiba, v. 21, n. 3, p. 345-351, 2015.

TORRES, F. T. P.; RIBEIRO, G. A.; MARTINS, S. V.; LIMA, G. S. Correlações entre os elementos meteorológicos e as ocorrências de incêndios florestais na área urbana de Juiz de Fora, MG. Árvore, Viçosa, v. 35, n. 1, p. 143-150, 2011. TORRES, F. T.; LIMA, G. S.; COSTA, A. G.; FÉLIX, G. A.; SILVA JÚNIOR, M. R. Perfil dos incêndios florestais em Unidades de Conservação brasileiras no período de 2008 a 2012. Floresta, Curitiba, v. 46, n. 4, p. 531-542, 2016.

WESTERLING, A. L.; BRYANT, B. P. Climate change and wildfire in California. Climatic Change, Hoboken, v. 87, p. 231-249, 2008.

WHITE, B. L. A.; RIBEIRO, G. T.; SOUZA, R. M. Caracterização do material combustível e simulação do comportamento do fogo em eucaliptais no litoral norte da Bahia, Brasil. Floresta, Curitiba, v. 44, n. 1, p. 33-42, 2014. 